\title{
Extracurricular Activities of the McClellan Committee
}

\author{
Paul Jacobs*
}

ROBERT KENNEDY's first reaction to the Government's most recent and R fourth failure at obtaining a conviction of Jimmy Hoffa is not certain. But whatever it was, whether or not he clasped his head and moaned when he heard the jury was unable to reach a verdict, it is almost certain that, some time soon, he will try again to put Hoffa in jail. And perhaps he will succeed, for it does not seem possible that Hoffa, even with the giant resources of the Teamsters Union at his command, can elude, forever, the gigantic effort being made by the Justice Department to jail him.

The bitter feud between Kennedy and Hoffa has been the subject of much discussion ever since it began in 1957. But the public discussion of it has tended, inevitably, to focus on the personalities of the two men who are involved, for they are each other's public and private "bête noire." Because the dramatic interest in this personal conflict is intense, some larger issues have been obscured. One of these is the delineation of what limits should exist for the activities of a congressional committee outside its legislative and investigative role.

The empowering mandate of the Senate Select Committee on Improper Activities in the Labor or Management Field, more familiarly known as the McClellan committee, was to

conduct an investigation and study of the extent to which criminal and other improper practices or activities are, or have been, engaged in the field of labor-management relations or in groups or organizations of employees or employers, to the detriment of the interests of the public, employers or employees, and to determine whether any changes are required in the laws ... in order to protect such interests against the occurrence of such practices or activities. ${ }^{1}$

Did the committee overstep that mandate in both its conduct of the hearings and the involvement of its staff in extracurricular activities? During the hearings, for example, when Robert Kennedy was questioning a friendly witness about a wildcat strike in St. Louis that had occurred when some union members attempted to prevent the union from placing Negro drivers, he was quick to lead the witness away from revealing his

* Author, HSG, San Francisco, California; Staff Member, Center for the Study of Democratic Institutions, Santa Barbara, California.

${ }^{1}$ Hearings Before the Senate Select Committee on Improper Activities in the Labor or Management Field (pts. 1-58), 85th Cong., 1st \& 2d Sess., 86th Cong., 1st Sess. 1 (1957-1959). 
own racial bias. ${ }^{2}$ On another occasion, the committee was raising a great row about the spectre of an alliance between the Teamsters and the International Longshoremen and Warehousemen's Union under Harry Bridges. ${ }^{3}$ Louis Goldblatt, secretary-treasurer of Bridges' union, was confronted at the hearings with evidence of his Communist youth in $1934^{4}$ and Hoffa was questioned at length about the alliance. ${ }^{5}$ To further cinch this case against Hoffa, Kennedy pointed out that the ILWU had been expelled from the CIO for following the Communist Party line and that in contrast to the Teamsters, the east coast longshoremen had indignantly refused to be part of any deal with Bridges. ${ }^{6}$ However, Kennedy neglected, at the time, to also point out to the committee that the east coast longshoremen he used as an example of political virtue had been expelled from the AFL-CIO for being dominated by racketeers at the very time they were expressing their righteous horror at the idea of being associated with Communists.

The committee was not above also using antiunion employers to discredit the Teamsters ${ }^{\tau}$ or capitalizing on a witness' recourse to the fifth amendment on some questions to ask other unrelated ones knowing that the fifth amendment would be used again in answer. ${ }^{8}$ And the committee charged, for example, that a conspiracy existed between Teamster officials and underworld characters to open Portland, Oregon, for gambling and prostitution. ${ }^{9}$ But when the final smoke was cleared from this fiery allegation, the committee's own star witness had been convicted while the Teamster official and the mayor, two of the committee's main targets, had been acquitted. ${ }^{10}$

David Previant, a Teamster lawyer, has listed the kinds of "gnilt" the committee used against the union:

We had guilt by association, guilt by marriage, guilt by eating in the same chop house, guilt by the general counsel's amazement, guilt by somebody else taking the Fifth Amendment, guilt by somebody else refusing to testify. But we think the "doozer" was the one that happened when the committee was taking testimony concerning a criminal case in which eight defendants were tried for eleven weeks; the jury was out only eight minutes and came in with the verdict of "not guilty." The police detective who

2 Id. (pt. 38), at 14387-88.

3 Id. (pt. 56), at 19602.

4 Id. (pt. 56), at 19609-13.

5 Id. (pt. 56), at 19734-36.

6Id. (pts. 45, 56), at 16401, 19734.

7 Id. (pts. 1, 39), at 39, 14662-63.

8 Id. (pts. 1, 35), at 35, 13236.

9 Senate Select Comm. on Inproper Activities in the Labor or Management Field, Interint Report, S. REP. No. 1417, 85th Cong., 2d Sess. 37-40 (1958).

10 International Teamster, June 1958, p. 18. 
helped prepare the case said the prosecution felt it was not a fair trial. The

Committee nodded in sympathy and agreement. This is guilt by acquittal. ${ }^{11}$

The entire question of how congressional hearings should be conducted in order to protect the rights of witnesses is, and has been for some time, a subject of continuous discussion and litigation. But the standards for the extracurricular behavior of a congressional committee staff have not been as well defined; when a staff is as activist in its orientation as was that of the McClellan committee under Robert Kennedy, the question can assume great significance.

There can be no do doubt, for example, that Robert Kennedy and the staff of the McClellan committee played a noninvestigative, extracurricular role (1) in the fight against Hoffa within the Teamsters Union, and (2) in assisting the anti-Hoffa representatives on the court-appointed board of monitors in their attempt to use the board as a vehicle for ousting Hoffa and in trying to persuade workers to vote against the Teamsters in a labor board election. Were these actions properly within the function of a congressional committee staff?

The initial extracurricular activity of the McClellan committee staff was focused around the lawsuit known as Cunningham v. English, ${ }^{12}$ which developed fron an internal fight within the union.

The case was born in the summer of 1957. Prior to the filing of the lawsuit, the McClellan committee had been investigating corruption and racketeering in unions, with particular attention being paid to the Teamsters. Robert Kennedy, who was then the committee counsel and especially interested in the affairs of Dave Beck and Jininy Hoffa, had gathered around hin a staff of investigators (niany of them former FBI agents) whose naiveté about unions and ignorance of union procedures were outweighed by their personal devotion to Kennedy and their commitment to the task of rooting out evil from the unions.

As the committee began its hearings, there was a sensational new headline every day, revealing some sensational new iniquity. On television screens, millions saw the very substance leak out of Dave Beck through the hundreds of holes punched in him by the barbed questions of the relentless Bobby Kennedy. And, off in the wings, coldly watching Dave Beck collapse under the heavy weight of his fifth amendment responses, was Jimmy Hoffa, confident that Beck's downfall meant his own election as Teanister president at the union convention scheduled for the fall of 1957. During the early stages of the investigation, Hoffa had been tried in federal court on charges of attempting to bribe an investigator for the 
committee, but he was acquitted-despite a movie taken by FBI agents showing him allegedly carrying out the bribery. ${ }^{13}$ This acquittal was just the first of the long series of frustrating setbacks Robert Kennedy has received in his campaign to jail Hoffa. (Before the bribery trial Kennedy had been so certain of Hoffa's conviction that he, Kennedy, announced that if Hoffa were not convicted, he would jump from the Capitol. Hoffa has not allowed him to forget this unfulfilled promise.)

On the surface, Hoffa was completely cocky about his forthcoming appearances before the committee, despite being indicted again by a federal grand jury in May 1957 just as the hearings got under way. This time the charge was wire tapping. When Hoffa's turn to appear before the committee finally did come, not uncoincidentally in the week before the Teamster convention that seemed almost certain to elect him president, Hoffa was contemptuous of Robert Kennedy and defiant of the committee's attempt to pin him down with a confession of wrongdoing. By the time Hoffa had completed the first of his numerous appearances before the committee, millions of TV screens and newspaper photos had made him so notorious that even the crews on the planes he flew would leave the cockpit to stare at him, fascinated by the aura of evil strength that had been projected around him.

It was during this hectic preconvention period that thirteen members of the Teamsters umon, from locals in the New York and New Jersey area, joined in an attempt to legally prevent the convention from being held. Although none of the thirteen men had known each other before, there had been a loose coalescence of two or three groups that had talked vaguely for months of doing something to change the leadership of the union.

One of the self-described leaders who brought the thirteen together was a former teamster member, John Patrick Kennedy, who had been expelled from the union. "Pat" Kennedy, as he's known, said:

$[P]$ rior to the convention in 1957-as a matter of fact, for some years preceding that-guys, me and guys like me, were fighting in our local unions about different matters. In some instances, when we were successful, the International used to come in and intercede.

Finally, me and a couple other guys got the idea we were shovehing shit against the tide by fighting on a local level, what we ought to do is see if we could do something on the International level. ${ }^{14}$

To "do something on the International level," Pat Kennedy conferred in June 1957 with Godfrey Schmidt, a New York attorney. ${ }^{15}$ A

18 N.Y. Times, July 20,1957, p. 1 , col. 8.

14 Deposition of John Patrick Kennedy, April 22, 1960, p.3, Cunningham v. English, supra note 12.

16 Ibid. 
short time later, Pat Kennedy and the thirteen plaintiffs met with Schmidt, "and Mr. Schmidt agreed to start the action."10 Cunningham, in whose name the suit to enjoin the holding of the convention was filed, had been involved in a number of prior actions against the union. He had also attempted, unsuccessfully, to get his own local investigated by a number of government agencies and the McClellan committee. ${ }^{17}$

Schmidt, their lawyer, had come to public attention in New York in a strange combination of ways, first as labor advisor to Cardinal Spellman, when the Cardinal attempted to break a strike of gravediggers in Catholic cemeteries in New York, ${ }^{18}$ and then as president of an organization known as "AWARE," devoted to keeping allegedly pro-Communist actors and actresses from working. ${ }^{10}$ Schmidt's own professional affiliation with the theatre world dated to the time he gave readings of childrens' poetry over the radio. ${ }^{20}$

The suit against the union was based primarily on evidence drawn from the Senate committee hearings. Liaison was quickly established between Robert Kennedy, the committee staff, Godfrey Schmidt, and the plaintiffs; ${ }^{21}$ a liaison that was to be maintained durmg the entire period of the case. Before the suit was filed, Schmidt, Pat Kennedy, and some of the other plaintiffs met with and talked frequently on the phone to Robert Kennedy and members of the McClellan committee staff; ; $^{22}$ the two groups shared a mutual interest in preventing Hoffa from becoming president of the Teamsters.

"Kennedy had a lot of information which we didn't have," Kennedy, and so Robert Kennedy shared some of the information the committee had with the plaintiffs. ${ }^{24}$ Members of the committee staff showed the plaintiffs convention credentials which had been subpoenaed by the committee and even provided them with photostats of the credentials to be used in the lawsuit. ${ }^{25}$ The committee staff "helped us in a lot of ways" to prepare the lawsuit, said Pat Kennedy. ${ }^{28}$

Ten days before the Teamster convention was scheduled to begin, Schmidt filed an action on behalf of his thirteen clients, asking Federal

$16 I d$. at 4.

17 Interview With Godfrey Schmidt, Dec. 1960.

18 Cogley, Report on Blackitsting: II Radio-Television 132 (Fund for the Republic 1956).

19 Id. at 129.

$20 I d$, at 132.

21 Deposition of Joln Patrick Kennedy, supra note 14, at 12-23.

22 Ibid.; Interview With Godfrey Schmidt, Dec. 1960.

23 Deposition of John Patrick Kennedy, supra note 14, at 17.

24 Ibid.

$251 d$. at 19.

20 Ibid. 
District Judge J. Dickinson Letts, an eighty-three year old jurist of the district court in Washington, D.C., to enjoin the convention froin being held. Schmidt charged that the convention was rigged and that the union constitution had been violated. In addition to the request for an injunction, the thirty page complaint also asked that the court appoint a "Board of Receivers or a Master in Equity or Masters" over the union. ${ }^{27}$

Judge Letts issued the preliminary injunction on the day before the convention was due to open. The union appealed, that same day, to the Court of Appeals for the District of Columbia in the first of more than forty appeals made from the decisions of Judge Letts. The court of appeals stayed the decision of Letts, stating that his injunction against holding the convention went "beyond the necessities of the situation."28 The court of appeals decision was then upheld by Chief Justice Warren sitting on circuit. ${ }^{20}$

The attorney for the union during this period was Martin O'Donoghue of Washington, who for many years has represented the plumbers' union. (A year later in the pattern that marked this entire case, Martin O'Donoghue shifted sides to become one of Hoffa's chief accusers.)

Because of O'Donoghue's successful fight against Schmidt, the union convention was held and Hoffa was elected president. At that time, he seemed to have triumphed over the combined efforts of the McClellan committee, Robert Kennedy, the FBI, and all the other forces that were so clearly bent on keeping him from office. But Hoffa's triumph was a very short-lived one.

A few days after the convention ended, Schmidt once again applied successfully to Judge Letts for an injunction, this time to prevent Hoffa and his supporters from actually taking office. Once more, Martin O'Donoghue went to the court of appeals to seek a reversal. But this time the union lost, for, even though the court again said that the "findings and conclusions" of Judge Letts "go further than necessary," the injunction was, in substance, upheld..$^{30}$ However, the judges of the court of appeals did call for a prompt trial and so on December 2, 1957, the case began.

In the meantime, Hoffa also went to trial on the wire tapping charge. The wire tapping trial ended in a hung jury and was then rescheduled for early January. ${ }^{31}$ By this time, however, O'Donoghue had ended his rep-

27 Mandelbaum, The Teamster Monitorship: A Lesson for the Future, 20 FED. B.J. 125, 126 (1960).

28 International Bhd. of Teamsters v. Cunningham, Civil No. 14141, D.C. Cir., Sept. 28, 1957.

29 Cunningham v. English, 78 Sup. Ct. 3 (1957).

30 International Bhd. of Teamsters v. Cunningham, Civil No. 14201, D.C. Cir., Nov. 4, 1957.

31 N.Y. Times, Dec. 20, 1957, p.1, col. 2. 
resentation of the union and was replaced by Edward Bennett Williams, who had successfully defended Hoffa against the bribery charge.

The earher close relationship between the plaintiffs in the case and the McClellan committee staff was maintained after the convention. According to Pat Kennedy, Robert Kennedy showed the plaintiffs copies of the questionnaire the committee had sent to all the Teamster locals, asking for data on the election of delegates to the convention. ${ }^{32}$

While the case of Cunningham v. English was being tried before Judge Letts, Schmidt and Williams entered into private negotiations to settle the suit. After only a few meetings, Schmidt wrote George Meany (whom he claimed he knew although Meany denied this ${ }^{33}$ ) a "personal and confidential" letter. In his letter, Schmidt said that Williams "made a 'confidential' proposal which I, of course, did not accept." "The "confidential' proposal," immediately made nonconfidential by Schmidt, involved setting up a trusteeship for the union but permitting Hoffa to remain in office.

"Of course, I could not agree to this. . . ." Schmidt wrote Meany. "I shall not consent to any agreement under which Hoffa retains office," he continued. "Nor, indeed, shall I consent to any settlement without getting your full approval," he told Meany, ${ }^{35}$ who never responded to the letter. ${ }^{30}$

Six weeks later, however, Schmidt signed a consent order on behalf of his clients, permitting Hoffa and the other union officers to take office "provisionally" and setting up a board of monitors to be paid by the union. According to the consent order, the district court retained jurisdiction over the monitors, who were subject to removal by the court. Further, the monitors were "subject as officers of the Court to supervision and direction of the Court in perforning their duties . . ." 37

As the first experiment in setting up a new type of legal supervision over unions, the consent agreement could not have been much worse. It came into being only because Hoffa was desperate to get the necessary legal ratification of his authority as union president without giving up any real power and because Schmidt was desperate to get the suit settled without giving up the major task to which he had committed himself-

32 Deposition of John Patrick Kelnnedy, supra note 14, at 19-20.

33 Deposition of Godfrey P. Schmidt, April 8, 1960, p. 22, Deposition of George Meany, April 26, 1960, p. 11, Cunningham v. English, Civil No. 2361-57, D.D.C.

34 Letter From Godfrey P. Schnidt to George Meany, Dec. 16, 1957.

35 Ibid.

30 Deposition of George Meany, stcpra note 33, at 10; Deposition of Godfrey P. Schmidt, supra note 33, at 18.

37 Consent Order, Cunningham v. English, Civil No. 2361-57, D.D.C., Jan. 31, 1958, reprinted in Mandelbaum, supra note 27, at 148-50. 
to "keep Hoffa and his henchmen from office."38 And so a useless compromise was worked out-a compromise between the principle of business trusteeship wherein the trustees have authority to conduct the affairs of the business and the principle that union affairs are best conducted with a minimum of interference from the outside.

The agreement was more satisfactory to the lawyers than to their clients. Hoffa was not especially happy with being able to take office only "provisionally." But he was persuaded that even if the union won the case, the decision would be appealed and the injunction against his taking office kept in force while the appeal made its long way through the higher courts. Hoffa had wanted the presidency of the union too long and too much to have it kept from him then. So, reluctantly, he approved the agreement.

Pat Kennedy, who along with Schmidt represented the plaintiffs in the negotiations that led to the consent decree, stated that the plaintiffs, too, were dissatisfied with the agreement because what they had

"started out to do here is to have a new election, and, according to the terms of this, the guys that were elected there are now going to be seated."

Not only that- -we were not satisfied with the terms of the consent decree, itself. In our opinion, it was too ambiguous. There was a lot of holes in it, and there was a lot of things we just didn't-we didn't hold still for it. It didn't embody what we started out to do.

That was what our guys said, and Mr. Schmidt told us, in pretty plain English, that we would bloody well have to hold still for it because if we didn't hold still for this consent decree the only alternative was to go back to trial and Mr. Schmidt was not prepared to continue the trial. ${ }^{39}$

As the board of monitors started to function, Schmidt and the plaintiffs chose himself as plaintiffs' monitor; the union picked one of its attorneys, Nat Wells; and both parties selected retired Judge Nathan Cayton who was appointed chairnian by Judge Letts. ${ }^{40}$ Meanwhile, Robert Kennedy and the staff of the McClellan committee continued their active interest in the situation, meeting often with Schmidt and the plamtiffs to discuss strategy. ${ }^{41}$

On the surface, the first few months of the monitorship were fairly smooth. But the honeymoon of the monitors' menage-à-trois and Hoffa lasted only a few months. By the time that Judge Cayton, the first chair-

38 Letter From Godfrey P. Schmidt to George Meany, Dec. 16, 1957; Deposition of Godfrey P. Schmidt, supra note 33, at 75; Deposition of John Patrick Kennedy, supra note 14, at 32,37 .

30 Deposition of John Patrick Kennedy, supra note 14, at 27.

40 See Consent Order, supra note 37.

41 Interview With Godfrey P. Schmidt, Dec. 1960; Deposition of Godfrey P. Schmidt, suspra note 33 , at 74 . 
man, resigned in May 1958, there were signs of grave troubles within the monitorship. As an instrumentality of the court, the consent agreement was obviously being interpreted quite differently by the parties to it and the judge who had approved it.

Hoffa believed that the monitorship was simply an expedient he had been forced to adopt in order to prevent a lengthy court suit that would keep him from office indefinitely. In his mind, the monitorship was going to last only one year, after which the union would hold another convention and he would be again elected president. Equally important to Hoffa was the principle that, during their year of service, the monitors were to have purely advisory functions; they were only to assist the union's executive board in carrying out its responsibihties. ${ }^{42}$

Hoffa's attitude about the role of the monitors was shared, quite naturally, by the union's first monitor, one of its lawyers, Nat Wells. ${ }^{48}$ Judge Cayton, the chairman, appointed by Judge Letts, also seemed inclined to view the monitors in this same advisory capacity.

But not Godfrey Schmidt. In his mind and certainly in that of his clients, the consent agreement under the court order gave the monitors far more authority than either Wells or Cayton believed they had. ${ }^{44}$ To Schmidt, "one of the primary means, one of the indispensable nieans" for the board to accomplish its mission was to oust Hoffa. ${ }^{45}$ This view of the monitorship was shared, evidently, by Robert Kennedy and his staff, who were contmuing their investigation of Hoffa and their attacks upon him.

There were other differences, too, of not quite such a principled character, developing among the monitors, mostly over their fees and expenses. Indeed, before the monitorship ended and even afterwards, a bewildering number of actions were instituted by Schmidt and other lawyers, asking for fees from the union. These suits ranged in scope from the $\$ 350,000$ requested on February 13, 1958, by Schmidt and his two colleagues for six months' service as plaintiffs' counsel in Cunningham v. English to somewhat more modest requests by other attorneys. ${ }^{46}$

In the middle of May 1958, Judge Cayton suddenly resigned as chairman of the monitorship. In his letter of resignation to Judge Letts, Judge Cayton stated that the monitors had "made excellent progress toward achieving the objectives stated" in the consent order. "Our work is in

42 Interview With James R. Hoffa, Dec. 1960; see Mandelbaum, supra note 27, at 128.

43 Initial Report of the Board of Monitors, Cunningham v. English, Civil No. 2361-57, D.D.C., at 195-204 (1958).

44 See $i d$. at 165-94.

45 Deposition of Godfrey P. Schmidt, supra note 33, at 74-75.

46 See, e.g., International Bhd. of Teamsters v. Schmidt, No. 15672, D.C. Cir., June 13, 1960; International Bhd. of Teamsters v. Dodd, No. 14733, D.C. Cir., June 12, 1959. 
such shape," wrote Judge Cayton, "that a new Chairman can take over with little or no loss of continuity."

As a prophet, Judge Cayton was not very prescient. Whatever tensions had existed within the monitors and between the monitors and the union officers soon becanie the kind of strains which so weakened the structure of the monitorship that it soon degenerated almost completely into loud shouting, bickering, and disputing. ${ }^{48}$

Two weeks later, over the vigorous objections initially of Godfrey Schmidt, Judge Letts appointed as impartial chairman of the monitors Martin O'Donoghue, who had represented the Teamsters aganist Schmidt in the original lawsuit. But only a week later, Schmidt wrote Judge Letts to tell hin that he had changed his mind about O'Donoghue who had, Schmidt said, "already taken action that I regard as more prompt, more just and more efficient than has been the case with the Board up to this time." Schmidt was particularly pleased, he informed Judge Letts, by O'Donoghue's "frank views on labor leaders who take the Fifth Amendment when questioned about their handling of union funds and stewardship." ${ }^{49}$ Schmidt also wrote Judge Letts that O'Donoghue shared the view that the inonitors "must not merely sit back and wait for con1plaints, but must take the initiative and follow the leads given to us by the McClellan committee." 50

As allies, O'Donoghue and Schmidt constituted a majority of the monitors, and with the help of the McClellan committee staff began actively moving against Hoffa..$^{51}$ By the summer of 1958 , O'Donoghue already was meeting with Robert Kennedy, utilizing the facilities and staff of the McClellan committee. ${ }^{62} \mathrm{He}$ had also moved his office as chief monitor out of the Teamster building and hired a staff of his own. Instead of making recommendations, O'Donoghue began issuing "Orders of Recoinmendation." Most of these actions were taken over the strenuous objections of the union monitor and the union but with the approval of Schmidt

47 Initial Report of the Board of Monitors, supra note 43, at 43-44.

48 Interview With Martin F. O'Donoghue, Dec. 1960; Interview With Lawrence T. Smith, Dec. 1960.

${ }^{49}$ Letter Fron Godfrey P. Schmidt to Hon. F. Dickinson Letts, June 3, 1958. "Glory be to God," said Martin O'Donoghue, "what is there to incriminate you by not testifying to an honest election?" Deposition of Martin F. O'Donoghue, April 6, 1960, Cunninghain v. English, Civil No. 2361-57, D.D.C., at 131.

50 Letter Froln Godfrey P. Schmidt to Hon. F. Dickinson Letts, June 3, 1958.

51 Interview With Godfrey P. Schmidt, Dec. 1960; Interview With Martin F. O'Donoghue, Dec. 1960; see Deposition of Martin O'Donoghue, supra note 49, at 64, 124; Deposition of Godfrey Schmidt, supra note 33 , at 74 .

52 Interview With Martin O'Donoghue, Dec. 1960.

53 Mandelbaum, Teamster Monitorship: A Lesson for the Future, 20 FED. B.J. 125, 128 (1960). 
and of Judge Letts, whose decisions were consistently appealed and very often reversed or modified by the court of appeals..$^{54}$

At the end of only a few months, the war was on in earnest between Hoffa and O'Donoghue, who was supported by Schmidt and the McClellan committee staff. "We had a lot of things going back and forth," said O'Donoghue, discussing his relationship with the committee staff. ${ }^{50}$

And while the raging disputes over the monitorship between Hoffa and O'Donoghue, flanked by Schmidt, were cluttering the dockets of the federal courts, Robert Kennedy was continuously subjecting Hoffa to the pitiless glare of exposure. Moreover, the committee staff was not only actively cooperating with the anti-Hoffa monitors, but early in 1959, Carmine Bellino, the committee's chief accountant, advised members of an independent umion not to affiliate with the Teamsters. ${ }^{\text {BB }}$

In June 1959, the court of appeals held that there was a "conflict of interest" in Godfrey Schmidt's role as monitor because he also represented employers who dealt with the Teamsters. ${ }^{57}$ Schmidt resigned and as his replacement proposed Terence McShane, an FBI agent who had testified against Hoffa im the earlier wire tapping case and who had been in virtually constant contact with Schmidt while Schmidt was a monitor. ${ }^{58}$ But the plaintiffs, who by this time were beginning to split annong themselves and were becoming dissatisfied with Schmidt, rejected McShane and nominated instead Lawrence Smith, who had been an attorney in Schmidt's New York office.

Despite his resignation from the board of monitors, Schmidt still represented some plaintiffs and maintained contact with the board ${ }^{60}$ as did Robert Kemiedy, ${ }^{60}$ despite his having resigned as counsel for the McClellan committee in September 1959, in order to run his brother's primary campaign.

One interesting example of the cooperation between the committee and the anti-Hoffa monitors during this period occured when Walter Sheridan, a committee investigator, went to Joplin, Missouri, in December 1959 to interview a prisoner, Carl Cates, in jail for parole violation. ${ }^{01}$ Previously, while out on parole, Cates had been a janitor for a Teamster local in Springfield, Missouri, some of whose records were allegedly inissing. Under questioning, in the presence of his parole officer and the attorney

54 See, e.g., English v. Cunningham, 269 F.2d 517 (D.C. Cir.), cert. denied, 361 U.S. 905, 909-10 (1959); Mandelbaum, supra note 53, at 128-30.

65 Interview With Martin O'Donoghue, Dec. 1960.

56 Affidavit of John Coppa, March 25, 1959.

67 English v. Cunningham, supra note 54, at 526.

58 Deposition of Godfrey P. Schmidt, supra note 33, at 35-44.

${ }^{59}$ Letter From Lawrence T. Smith to Godfrey P. Schmidt, Feb. 16, 1960.

BO Ibid.; Interview With Martin F. O'Donoghue, Dec. 1960.

61 Interview With Walter Sheridan, Dec. 1960. 
for an anti-Hoffa group in the local union, the prisoner told Sheridan that he had seen some of the union officers taking boxes of union records from the hall and putting them in their cars. Cates said later he was not sure just who Sheridan ("Walt") was nor whom he represented. Despite this uncertainty, Cates signed an affidavit about what he had allegedly seen and the next day was released from prison.

A few months later, attorneys for the anti-Hoffa monitors who were checking into the disappearance of the same union records took an oral deposition from the ex-janitor in the presence of the attorneys for the union. But this time when Cates was questioned about whether he had seen the union officers take out the records, he denied it. The anti-Hoffa monitor lawyers, obviously shocked, produced the affidavit which Cates had given to Sheridan and which Sheridan had, in turn, turned over to them but not to Hoffa's lawyers nor the union-appointed monitor.

Why had Cates given Sheridan the original affidavit that he later recanted? One possible explanation is that his parole officer had told him "that if I didn't try to help them that I couldn't expect any help myself." Cates identified the "them" as "Walt" and the "state officials" with him.".3 The parole officer who had been with Sheridan at the jail and was present also at the deposition declined to discuss the incident on the record. ${ }^{64}$ Within forty-eight hours after the ex-convict had reversed his story he was once more a convict, sent back this time again for parole violation. ${ }^{65}$

Early in 1960, the running legal brawl into which the monitorship had degenerated by then erupted into an even nore complicated situation. Lawrence Smith, Schmidt's successor as monitor, refused to sign an interim monitors' report that O'Donoghue, backed by Schmidt and Robert Kennedy, hoped to use as the basis for ousting Hoffa from the union. The report had been drawn up from material gathered by the McClellan coinmittee, ${ }^{6 B}$ but Smith believed it was "not designed to pronote any policy which would implement the purposes of the Consent Decree." said Smith, he doubted whether O'Donoghue had any long-range policy except to "oust Hoffa as Provisional General President."

O'Donoghue also attempted during this period to hire Walter Sheridan and was prevented from doing so only by the court of appeals which stayed Judge Letts' informal order approving O'Donoghue's request. ${ }^{69}$

02 Deposition of Carl Cates, March 23, 1960, p. 370, Cunningham v. English, Civil No. 2361 -57, D.D.C.

03 Id. at $370-71$.

64 Id. at 370 .

${ }^{65}$ Springfield (Mo.) Leader-Press, March 26, 1960, p. 10.

60 Deposition of Lawrence T. Smith, April 21, 1960, p. 28, Cunningham v. English, Civil No. 2361-57, D.D.C.

67 Letter From Lawrence T. Smith to Godfrey P. Schmidt, Feb. 16, 1960.

88 Ibid.

69 Interview With Martin F. O'Donoghue, Dec. 1960. 
At this time Robert Kennedy was actively at work on his brother's primary campaign. But on February 15th, according to Godfrey Schmidt, Kennedy took time out from the campaign to call Schmidt, complaining that Lawrence Smith had refused to sign the report prepared by O'Donoghue's staff. ${ }^{70}$

But despite the pressure exerted directly on him by Schmidt, ${ }^{71}$ and indirectly by Kennedy, through Schmidt, ${ }^{72}$ Smith refused to sign the report. The break between Smith and Schmidt, backed up by Kennedy, was characteristic of the Borgia-like atmosphere which flourished in this period, replete with plots and counterplots, proposals and propositions, secret meetings, and hurried phone calls. Schmidt was having confidential sessions with Edward Bennett Williams about ending the monitorship and promptly reporting to the FBI, Robert Kennedy, and Judge Letts. ${ }^{73}$ Lawrence Smith and Schmidt had become such bitter enemies that six of the original plaintiffs in the lawsuit attempted to break off their relationship with Schmidt, but Judge Letts refused to allow them to do so. ${ }^{74}$ At Schmidt's request, Judge Letts also removed Smith as monitor, putting McShane in his place. ${ }^{75}$ Smith, supported by the six anti-Schmidt plaintiffs, appealed Letts' decision to remove him; on May 12th and 13th the court of appeals stayed Judge Letts' order removing Smith from the board ${ }^{76}$ and decided that the six plaintiffs had a right to drop Godfrey Schmidt and retain new counsel. ${ }^{77}$ Five days later, two of the six plaintiffs were invited to attend a meeting in Robert Kennedy's New York apartment. Walter Sheridan, Terence McShane, Robert Kennedy, and one of the plaintiffs still loyal to Schmidt. were also present at the meeting. The purpose of the session was to attempt to persuade the two plaintiffs who had broken with Godfrey Schmidt that they ought to go back to him and that they should accept McShane as their monitor nominee instead of Lawrence Smith. The two disgruntled plaintiffs refused both requests and angrily left Kennedy's apartment. ${ }^{78}$

70 Interview With Godfrey P. Schmidt, Dec. 1960; see Letter From Lawrence T. Smith to Godfrey P. Schmidt, Feb. 16, 1960.

71 Interview With Lawrence T. Smith, Dec. 1960.

72 Ibid.

73 Letter From Godfrey P. Schmidt to Edward Bennett Williams, Feb. 16, 1960; Letter From Godfrey P. Schmidt to Hon. F. Dickinson Letts, Feb. 19, 1960.

74 Mandelbaum, supra note 53, at 136; Deposition of Godfrey P. Schmidt, supra note 33, at 30 .

75 Mandelbaum, supra note 53, at 136-37.

76 Milone \& Smith v. English, Civil No. 15715, D.C. Cir., May 12, 1960. On June 2, 1960, the court of appeals entered its decision vacating Judge Letts' order of removal. Mandelbaum, supra note $\mathbf{5 3}$, at 137 .

77 Milone v. English, Civil No. 15713, D.C. Cir., May 13, 1960.

78 Affidavit of Terence F. McShane, Sept. 12, 1960, Cunningham v. English, Civil No. 2361-57, D.D.C.; Affidavit of Steve Milone, May 19, 1960; Affidavit of Jolen McManus, May 19, 1960. 
Quite apart from a dispute about what actually was said at the meeting (Did Robert Kennedy call one of the two plaintiffs a son of a bitch? Did he imply that when his brother was President help would be available?), there is a far more serious question involved here. As a private citizen, Robert Kennedy certainly has a right to be interested and concerned with the future of the Teamsters Union, but the fact is that, at the time, he was much more than just an ordinary private citizen. His initial involvement in the affairs of the Teamsters Umion was as a congressional employee. His role vis-á-vis the monitors was derived from his position as counsel for that committee. His ability to possibly influence the decision of the six plaintiffs to return to the arms of Godfrey Schmidt and substitute McShane for Smith was due precisely to his special position. And what was true of Robert Kennedy was equally valid for Walter Sheridan.

Let me recapitulate the argument and attempt, simultaneously, to narrow it. From the start of Robert Kennedy's investigation of the Teamsters Union, he has been convinced that the umion, under Hoffa's leadership, represents a "conspiracy of evil," and that the good of the country requires the jailing of Hoffa, if possible, and at least ousting him from the union presidency. Kennedy has been committed, openly and totally, to these two objectives. ${ }^{79}$

To accomplish these ends, Kennedy was willing to use the legal power and the staff at his disposal as counsel for a congressional committee to assist the anti-Hoffa teamsters in their private lawsuit to prevent the 1957 union convention from being held. Kennedy believed that the convention had been rigged for the purpose of electing Hoffa. ${ }^{80}$ This has been disputed by Solicitor General Archibald Cox who said, in 1959, "Apparently there were widespread violations of the constitution and bylaws of the International Brotherhood of Teamsters in the choice of delegates for the 1957 convention but many of them were technical and no one seriously believes that the majority of the members desired a different president."

When the attempt to enjoin the convention failed because, as Chief Justice Warren said, it called "for an extraordinary exercise of judicial power" and the court took over supervision of the union's affairs through the board of monitors, the congressional committee intervened actively and continuously in the affairs of the monitorship. During the life of the board, the committee, under the direction of Kennedy, lent its resources to the anti-Hoffa monitors in their attempt to use the board as an instru-

${ }^{70}$ See KenNedy, The Eneary WItHin (1960).

80 Ibid.

81 Cox, The Role of Law in Preserving Union Democracy, in LABOR IN A Free Soctety 67 (Harrington \& Jacobs ed. 1959). 
ment for ousting Hoffa from the union presidency and preventing a union convention from being held. Once again, these attempts were frustrated by the appellate courts. The Court of Appeals for the District of Columbia reversed fifteen of Judge Lett's decisions in favor of the anti-Hoffa monitors and reversed in part or substantially modified several others.

In this sense, il was the court of appeals that stood between Hoffa and those momitors, supported and sustained by the McClellan committee staff, who were intent on using the monitorship as a device for ridding the union of Hoffa. As Justice Frankfurter said, the court of appeals "manifested an alert understanding of the gravity of the litigation, and has made manifest its sense of the high importance of assuring the most protective procedure on the part of the Board of Monitors . . .."82

At that point, frustrated by the court of appeals decision reversing the dismissal of monitor Lawrence Smith, Robert Kennedy attempted to accomplish the dismissal by a private meeting with two of the plaintiffs.

Jimmy Hoffa and the Teamsters Union are the antithesis of what I believe a union leader and a union ought to be. But nyy feelings about Hoffa are only important insofar as they affect what I write about him. Robert Kennedy's behavior toward Hoffa is of far greater significance, for Kennedy is not a private citizen-he is a public servant, and what he does about Hoffa involves not only himself but the very Government itself. As staff counsel for the McClellan committee and as Attorney General, he acts in a public capacity in the nanie of every citizen. As a result he is open to judgment about how he exercises that responsibility.

The Kennedy-Hoffa feud has many political and moral dimensions which need examination, but it seems clear to nie that the McClellan committee's direct involvement in the Cunningham v. English law suit, and in the ensuing affairs of the board of monitors, went far beyond the committee's specific mandate and the general niandate of congressional committees. The evidence demonstrates to me that the committee and its staff, under Robert Kennedy's direction, trespassed heavily upon the rights of Hoffa and the union.

It is a cliche and a truism that the most important civil rights are those of our enemies - of the people with whon we disagree. And so, although I have nothing in common with Hoffa, the umion leader, Hoffa, the citizen, is me. His rights are the same as mime and require the same protection. 